\title{
The Long-term Effects of Political Violence on Political Attitudes: Evidence from the Spanish Civil War
}

\author{
Daniel Oto-Peralías* \\ // Accepted Manuscript: Kyklos, 68(3), 412-442. //
}

\begin{abstract}
This article investigates whether political violence has long-term effects on attitudes toward political participation. This is an interesting topic because public engagement and social capital play a crucial role in shaping the economy and democracy. We exploit a recent survey on the 1936-1939 Spanish Civil War to shed light on this question. Our findings indicate that being a member of a family that suffered violence during the Civil War is related to a higher interest, knowledge and engagement in politics. These results stand in stark contrast to the common expectation that political violence leads to lower public engagement, while they are consistent with other studies focusing on the short-term consequences of civil conflicts. Therefore, the legacy of political violence, far from creating political apathy, may be the higher involvement of citizens in politics.
\end{abstract}

Keywords: Political Violence, Political Attitudes, Social Capital, Spanish Civil War JEL Classification: D72, D74, D79

\footnotetext{
* Universidad Pablo de Olavide, Departamento de Economía, Métodos Cuantitativos e Historia Económica, Carretera de Utrera, Km. 1, Seville, 41013, Spain. E-mail: dotoper@upo.es.
}

Acknowledgements: I thank Diego Romero-Ávila, Jesús Crespo-Cuaresma, Carlos Usabiaga and seminar participants at Pablo de Olavide University for their valuable comments and suggestions. I am particularly indebted to the editors and referees of this journal for many valuable comments that have led to a substantial improvement of the original manuscript. The author acknowledges financial support from the Spanish Ministry of Economy and Competitiveness through grant ECO2012-35430, and the Andalusian Council of Innovation and Science under Excellence Project SEJ-4546. 


\section{INTRODUCTION}

The consequences of political violence, particularly of civil wars, are topics that have attracted considerable interest in recent years (Blattman and Miguel, 2010). According to the World Bank (2011), one in four people in the world, more than 1.5 billion, live in countries affected by fragility, conflict, and violence (Balcells and Justino, 2014). Civil conflicts incur dramatic costs in terms of both human lives and well-being, with the accompanying destruction of public infrastructure and physical capital (Welsch, 2008; Gates et al., 2012). In addition to these human and material losses, an interesting finding in the literature is that political violence may leave significant institutional and political legacies (Blattman and Miguel, 2010). This article covers a subject that has so far been little studied, namely, the long-term effects of political violence on attitudes related to political participation. Arguably, this is a relevant topic because economists and political scientists have long emphasized the importance of political participation and social capital for the economy and governance (e.g., Putnam et al., 1993; Knack and Keefer, 1997; Sabatini, 2008). If political violence had persistent negative effects on political participation, then a civil war might undermine a country's development prospects. Using a recent survey on the political legacy of the Spanish Civil War, we show that the consequences of this war fought seventy years ago continue to influence political attitudes today. Interestingly, we find a heartening result: past political violence is positively related to attitudes toward political participation.

A preliminary analysis at cross-province level provides initial evidence of a positive relationship between political repression during the Spanish Civil War and electoral turnout since the re-introduction of democracy in the mid-to-late 1970s. The core of the analysis uses microdata from a survey conducted in 2008 (CIS, 2008), which contains a representative sample of almost 3,000 individuals. The regression results indicate a robust positive effect of political violence on political attitudes. More specifically, reporting direct/indirect political violence during the Civil War is positively associated with higher interest, knowledge and engagement in politics. ${ }^{1}$ We seek to address endogeneity concerns through different strategies, such as controlling for family political identities during the Civil War, or focusing on the most randomly distributed types of violence. The results are robust to controlling for

\footnotetext{
1 'Reporting direct/indirect political violence' means that the respondent suffered political violence during the Civil War, or that a relative or someone close was the victim of political violence during the Civil War.
} 
many individual characteristics, as well as for regional fixed-effects. Interestingly, the effect of political violence persists when restricting the sample to younger adults (who were born long after the war), and is not associated with political extremism. Family socialization is a key factor in the transmission of the effect over time.

This work is interesting for several reasons. Firstly, it focuses on the long-term consequences of political violence and civil wars, while the extant literature has generally studied the shortterm effects. For example, Bellows and Miguel (2009) study the consequences of the 19912002 Sierra Leone Civil War; Blattman (2009) analyzes the ongoing Lord's Resistance Army insurgency in Uganda; Beber et al. (2014) base their research on an episode of violence during a spontaneous riot in 2005 in Sudan, and Gilligan et al. (2014) focus on the 1996-2006 Nepalese Civil War. In contrast to these studies, our data come from a survey conducted in 2008, and referred to a seventy-year-old conflict. Studying the long-term effects of political violence is pertinent. If the effects continue to be apparent today, it indicates that political violence is a deep and permanent determinant of political attitudes, and that the legacy of war can have a long-term influence on the political system.

Secondly, this work also contributes to the vibrant literature on the causes and consequences of cultural traits, since political attitudes and public engagement are important socio-cultural aspects. $^{2}$ This branch of the literature typically focuses on historical events as determinants of cultural traits. Notably, several papers look back into the past for the roots of social capital and civic culture. For instance, Guiso et al. (2008) test the hypothesis formulated by Putnam et al. (1993) whereby the Italian city states that gained independence in the High Middle Ages developed higher levels of social capital. Alesina and Giuliano (2011) report an inverse relationship between family ties (a persistent cultural feature of societies) and political participation. Puntscher et al. (2014) argue that historical shocks may affect social capital endowment by shaping collective memory. In addition, even such exogenous shocks as natural disasters have been found to influence social capital (Toya and Skidmore, 2014). Our paper contributes to this literature by showing that a historical event in the thirties, the Spanish Civil War, has persistently affected the political attitudes of citizens. This is even more notable when considering that the war was followed by a period of almost forty years of dictatorship, and then by a transition to democracy within a context of instability.

\footnotetext{
${ }^{2}$ Reviews of the literature are to be found in Guiso et al. (2006), Nunn (2012), and Alesina and Giuliano (2015).
} 
Thirdly, this study also addresses the question of whether the lack of interest in politics in Spain is due to the extreme political violence suffered during the Civil War. Interest in politics is particularly low in Spain. According to an international survey on citizenship conducted in 2004, and covering 39 countries as diverse as the United States, Philippines or Russia (ISSP 2004), Spain records the fourth lowest score in terms of interest in politics, just ahead of Cyprus, Brazil and Taiwan. Only $31 \%$ of respondents are very or fairly interested in politics. Given Spain's income per capita, this is a remarkably low figure. According to the modernization theory (Lipset, 1959), one expects higher economic development to be reflected in greater interest and engagement in politics. In fact, Spain has the highest negative residual in a regression of interest in politics on per capita GDP. ${ }^{3}$ In this regard, an intuitive explanation for the lack of interest in politics would be the political violence suffered during the Civil War, which would have left a deep imprint on society. Violence and repression could be responsible for an attitude of political apathy in society, making people reluctant to engage in politics. However, our results clearly reject this hypothesis, since growing up in a family that suffered political violence during the Civil War is positively related to interest in politics. These apparently counterintuitive results are also found in other papers that focus on the short-term effects of civil conflicts (Bellows and Miguel, 2009; Blattman, 2009; Gilligan et al., 2014). However, to the best of my knowledge, this is the first paper to provide evidence of the long-term positive effects on attitudes toward political participation.

There are a couple of interesting articles that use the same survey to study different questions. Aguilar et al. (2011) analyze the determinants of attitudes toward transitional justice in Spain. They find that family victimization during the Civil War is not generally associated with support for such justice, while political repression during the Francoist dictatorship is. Balcells (2012) focuses on the effect family victimization has on political identities in the leftright axis, and shows that experiences of victimization during the Civil War and Francoist dictatorship are related to the rejection of the perpetrators' political ideology. Unlike these two papers, we focus on attitudes toward political participation. In addition, we seek to address the endogeneity issue involved in being a victim of political violence during the war, and complement the analysis with cross-province evidence of the relationship between political repression and electoral turnout.

\footnotetext{
${ }^{3}$ Details on the comparative results from the ISSP 2004 survey are available in the Supporting Information accompanying this paper.
} 
The remainder of the paper is organized as follows. Section 2 gives a brief historical overview and formulates plausible hypotheses about the effect of political violence on political attitudes. Section 3 presents some cross-province evidence. Section 4 reports the paper's main results using microdata from a survey sample. The next section conducts a sensitivity analysis and addresses the endogeneity issue. Section 6 provides evidence of possible intervening variables, while Section 7 considers a wide array of indicators of political attitudes, knowledge and engagement. Finally, Section 8 puts forward a number of implications and concludes.

\section{THE SPANISH CIVIL WAR AND CURRENT POLITICAL ATTITUDES}

The Spanish Civil War (1936-1939) has weighed heavily upon the history of Spain since the downfall of the Second Republic. ${ }^{4}$ The war was the consequence of a failed military coup against the democratically elected Republican government in July 1936. The coup succeeded in some provinces but not in others, and as a result, Spain was divided into two zones, one controlled by the rebels and the other by the Republican government. A fundamental aspect of the Civil War was its political nature. It was a struggle between two antagonist political forces: the insurgents or Francoists (called Nationalists), representing the political right, versus the loyalists or Republicans, representing the left. During the three years the war lasted, Spain became a scene of extreme political violence. The total number of deaths exceeded half a million, with around 220,000 being due to political repression. The war also caused a massive displacement of more than 400,000 people. The victory of the Nationalist army led to the establishment of a dictatorship that lasted until Franco's death in 1975 (the first democratic elections being held in 1977), with political repression continuing for years after the war. During and after the war, the Francoist regime was committed to purging all leftist elements in Spain, while the Republicans also committed political violence against civilians during the war itself, although current estimates clearly indicate that repression on the Nationalist side was far more widespread than on the Republican side (approximately 200,000 deaths vs. 38,000 , according to Beevor, 2006).

While these immediate effects of the war are evident, its long-term consequences on politics, culture and the economy are still largely unexplored. Given the conflict's extreme level of

\footnotetext{
${ }^{4}$ The literature on the Spanish Civil War is extensive. Among others, see Juliá et al. (1999), Thomas (2001), Beevor (2006), and Preston (2006).
} 
political violence, it stands to reason that it left a deep imprint on political culture and, more specifically, on attitudes toward political participation. ${ }^{5}$ With respect to the link between violent conflicts and political participation, there is some controversy both in the literature and in the political arena. In the first place, there is a hypothesis that supports the common expectation that civil war negatively affects public engagement. This is generally the view of policymakers, journalists, and reintegration experts, who consider that the impacts of a civil war on individuals engender alienation, violence and even social disintegration (Blattman, 2009). A similar opinion can also be found in a World Bank report stating that a epersistent adverse legacy [of civil war] is the loss of social capital' (Collier et al., 2003, p. 21). According to this hypothesis, we should find a negative relationship between experiencing violence during the Civil War and attitudes toward political participation. The argument would be that political violence triggers a rejection of politics. The war itself, as an extreme manifestation of a political conflict, can be seen as the consequence of too much political activism. This can create hate, fear or apathy toward politics in general, especially among the relatives or friends of the war's victims. In addition, this response to violence may be intensified if political repression is due to some kind of political activism (e.g., party membership or labor activism). Therefore, political violence can convey the message that participation in politics is dangerous, and it is better not to get involved. These attitudes can be transmitted from one generation to the next through family socialization, and thereby persist over time. This hypothesis would explain the current lack of interest in politics in Spain as being a consequence of the Civil War.

Second, a counterintuitive hypothesis would be that political violence increases public engagement (Blattman and Miguel, 2010). Notably, some papers focusing on the short-term effects of civil conflicts come to the surprising conclusion that being a victim (or witness) of political violence leads to higher post-war political participation (Bellows and Miguel, 2009; Blattman, 2009; Gilligan et al., 2014), which is related to psychological research into positive responses to traumatic events (Masten, 2001). Considering the Spanish case, an explanation consistent with this hypothesis is that a past episode of political violence suffered by an individual or their family may mean that politics is more prevalent in the life of the family, and prompts more political conversations and discussions. Furthermore, victimization may

${ }^{5}$ See Balcells (2012) for a study of the effect of victimization during the Civil War and Francoist dictatorship on ideological identification. 
generate political grievances and resentment, which may lead to political activism. This second hypothesis implies that the lack of interest in politics in Spain is due to factors other than the violence suffered during the Civil War.

Finally, it may also be the case that political violence does not have persistent effects on political attitudes, particularly when applied to Spain (because the war took place more than seventy years ago). According to this hypothesis, although the Civil War could have shortterm consequences for interest and engagement in politics, its effect has vanished over time, due -for example- to indoctrination during the dictatorship or to the important changes introduced by the advent of democracy in the mid-to-late seventies.

\section{CROSS-PROVINCE EVIDENCE}

This section provides regression evidence on the relationship between political violence and political participation at provincial level. The dependent variable is the average electoral turnout for all the parliamentary elections held in Spain since 1977 (from electoral data provided by the Spanish Government -Ministerio del Interior, 2014). Concerning the independent variable, we focus on deaths due to Francoist political repression defined as the ratio of victims to total population (in thousands), since this is the most readily available data at provincial level. For the sake of completeness, we also report the results using an indicator of Republican repression. ${ }^{6}$ Regressions are estimated through Ordinary Least Squares (OLS) reporting heteroskedasticity-consistent standard errors. Detailed information about the definitions and sources of variables used throughout the paper is presented in Appendix I, while the descriptive statistics are available in the Supporting Information.

Column 1 in Table 1 shows the bivariate relationship between Francoist political repression and current electoral turnout. ${ }^{7}$ Interestingly, there is a positive and statistically significant relationship between both variables across Spanish provinces, which stands against a possible negative link between political violence and political participation (as predicted by the first

\footnotetext{
${ }^{6}$ We focus here on Francoist repression because it was much more prevalent, and the sample of provinces for which data are available is larger. A word of caution is in order with respect to these data. The total number of deaths caused by the Spanish Civil War is a subject of uncertainty and controversy. The same is true for data at provincial level. We follow Juliá et al. (1999) and Espinosa-Maestre (2008) for data on political repression.

${ }^{7}$ The specification includes a dummy variable indicating whether data on Nationalist political repression have been only partially investigated (which is the case in six provinces). It is important to include this variable in order to control for the fact that the value of political repression in these provinces may be lower simply because they have been only partially investigated.
} 
hypothesis presented above). Column 2 includes four variables that may act as determinants of political repression; these are, on the one hand, two indicators of the last parliamentary elections held in the Second Republic (in February 1936): the percentage of votes obtained by the left-wing coalition (which reflects the predominant ideology just before the Civil War), and the electoral turnout as a measure of political participation. On the other hand, we include two variables related to the dynamic of the coup and the war: a dummy variable indicating whether the military coup succeeded, and the number of days (since the coup) that the province remained under Republican control. These four indicators may be relevant omitted variables, biasing the coefficient on political violence in column 1. In this regard, it is particularly important to control for electoral turnout before the war. Remarkably, the coefficient on political repression remains positive and statistically significant. The next column adds two variables related to economic development, namely, per capita income and the percentage of working age population with secondary or higher education, while column 4 removes those provinces whose data on political repression have been only partially investigated. The coefficient on Francoist political repression remains robust to these changes in the specification. Concerning the control variables, the dummy 'successful coup', the number of days under Republican control, and electoral turnout in 1936 are positively and significantly related to current turnout. With respect to the repression perpetrated on the Republican side (columns 5 to 7 ), the coefficient is positive in the bivariate relationship, but becomes insignificant when including the control variables.

\section{[Insert Table 1 about here]}

Conclusions from this cross-province analysis are very tentative due to potential omitted variable biases and measurement errors. Yet the results are interesting for a couple of reasons. Firstly, this analysis at provincial level for Spain has not been conducted previously in the literature, and provides some plausible insights and correlations about the link between political violence and political behavior. Secondly, the results cast doubt on the intuitive hypothesis that political violence negatively affects interest and engagement in politics, since the coefficient on Francoist political repression is positively and significantly related to electoral turnout.

\section{SURVEY ANALYSIS}

\section{Data and methodology issues}


The core of our research consists of the analysis of a unique survey conducted in 2008 by the Centro de Investigaciones Sociológicas (CIS, 2008) that contains information about the political legacy of the Spanish Civil War and the subsequent Francoist dictatorship. Specific questions about personal and family experiences related to political violence were posed to a representative sample of 2,936 individuals aged 18 or older. This survey was possible because the Socialist Government at the time was promoting restorative actions regarding human rights violations perpetrated during these two periods, with the survey being designed to gather information about public opinion on these issues. The survey also contains other questions about the war period, as well as many items related to current political attitudes.

Our main dependent variable is interest in politics, measured through a dummy variable indicating whether the individual is very or fairly interested in politics. It is our main indicator of political attitudes because it is the best way of reflecting whether the individual is politically apathetic or not. Citizens interested in politics are individuals with positive attitudes toward the political sphere (including belief in the importance of participating in politics and of being informed about political affairs), and behaviors congruent with these convictions. In Section 7 we extend the analysis using alternative indicators of political attitudes, knowledge and behavior.

Political violence is the main independent variable, which consists of a dummy variable reflecting whether the respondent, a relative or someone close suffered political violence as a consequence of the Civil War. In the vast majority of cases, this variable refers to violence suffered by a relative or someone close (only 53 respondents report personal political violence, while 1,538 report violence suffered by a relative or someone close), which is understandable since the Civil War ended seventy years before the survey was conducted. There is also information about the specific type of violence and the identity of the perpetrator, which allows us to create several sets of indicators. Firstly, we construct three variables on the basis of which side in the conflict was responsible for the action: a) political violence perpetrated by Nationalists or Francoists, b) political violence perpetrated by Republicans, c) without information on the perpetrators. In a second set, following Balcells (2012), we differentiate between severe and moderate political violence. Severe political violence includes killed in action, died in bombing, murdered, condemned to death, disappeared, forced into exile, and all types of violence suffered by the actual individual. 
Moderate political violence reflects the other types of violence (imprisoned, forced into hiding, fired from work, and other situations). Finally, we also distinguish between political violence related to military operations and violence associated with political repression. The first category includes being killed in action and dying in bombing, while the second category refers to the remainder. ${ }^{8}$

A very simple and straightforward way to analyze the effect of political violence on political attitudes is by comparing respondents reporting direct/indirect political violence with those not reporting any political violence. In the first group, $38.3 \%$ of individuals are interested in politics, while in the second group only $25.4 \%$ are, with the difference being statistically highly significant $(t$-stat=7.01). Therefore, respondents reporting political violence are much more interested in politics, specifically $51 \%$ more so $(0.383 / 0.254-1)$.

However, it is crucial to control for omitted variables that might bias the estimated effect of political violence. In this regard, the choice of an appropriate set of control variables is not a trivial task. Some controls that may seem useful to include are actually channels through which the effect of political violence occurs. An important example is family political socialization, which can be measured through a question asking how often the respondent was exposed to conversations on politics at home. This variable clearly acts as a channel, as political violence during the Civil War could affect family behavior regarding the subject of politics at home, which in turn may influence current political attitudes. ${ }^{9}$ Another example is the respondent's political identity, which may be affected by political violence in the past, as shown in Balcells (2012). These two variables are clear instances of 'bad controls', that is, variables that can themselves be considered outcomes (Angrist and Pischke, 2009, Ch. 3).

With these concerns in mind, we have selected a set of sociodemographic controls that includes variables generally found in the political behavior literature, such as a person's age, gender, attitude to religion, size of municipality in terms of population, and level of education. A set of dummy variables indicating the region (Autonomous Community) in which the respondent resides is also included. It is important to take this factor into account because

\footnotetext{
${ }^{8}$ The Supporting Information provides a frequency table for these different classifications of political violence.

${ }^{9}$ In this regard, since people that directly experienced the Civil War are a tiny minority (only approximately $13 \%$ of the respondents were born before the outbreak of the war), the transmission of political attitudes and values from one generation to the next plays a central role in the observed results. Therefore, intervening factors in this process are not appropriate controls.
} 
political decentralization is high in Spain, and the quality and performance of regional governments can affect citizens' political attitudes. ${ }^{10}$ In addition, to address the endogeneity issue whereby families more involved in politics at the outbreak of the Civil War could have suffered more political violence, we always control for two variables indicating whether the respondent's family had political sympathy with one or other of the warring sides (Nationalists or Republicans), which may capture their level of political activism.

\section{Initial regression evidence}

The equation to be estimated is as follows:

$$
\begin{aligned}
\text { Int_Pol }_{i, r}= & \alpha+\beta_{1} * \text { Pol_Violence }_{i, r}+\beta_{2} * \text { Sociodem }_{i, r}+\beta_{3} * \text { Region }_{r}+\beta_{4} * \text { Nationalist }_{i, r}+ \\
& \beta_{5} * \text { Republicans }_{i, r}+\varepsilon_{i, r}
\end{aligned}
$$

where Int_Pol ${ }_{i, r}$ means the current interest in politics of individual $i$ in region $r$; Pol_Violence $_{i, r}$ stands for our main indicator of political violence; Sociodem ${ }_{i, r}$ represents the set of sociodemographic controls; Region $r$ is a set of dummy variables indicating the Autonomous Community where the respondent lives; Nationalist $t_{i, r}$ indicates whether the respondent's family sympathized with the Nationalists during the Civil War, Republicans ${ }_{i, r}$ means the same, but referred to the Republicans, and $\varepsilon_{i, r}$ is the error term. Since the dependent variable is a binary indicator, we use a logistic regression model with heteroskedasticityconsistent standard errors reporting odds ratios. ${ }^{11}$

Table 2 reports the paper's main results. Column 1 shows the bivariate relationship between political violence and current interest in politics. The coefficient indicates that individuals reporting direct/indirect political violence during the Civil War have $82 \%$ greater odds of being interested in politics (i.e., the probability of being interested in politics relative to the probability of not being interested) than those not reporting political violence. ${ }^{12}$ Column 2

\footnotetext{
10 The quality of government institutions influences political attitudes, as shown, for example, in Rohrschneider (2005) and Anderson and Tverdova (2003).

11 We prefer to report odds ratios in the main text because they are more informative than the logistic coefficients. For the sake of completeness, the Supporting Information also provides all the results with the logistic coefficients and their standard errors.

${ }^{12}$ In the previous section we indicate that $38.3 \%$ of respondents reporting political violence are interested in politics. Consequently, the probability of being interested in politics $(p)$ for this group is 0.383 , and the probability of not being interested in politics $(1-p)$ is 0.617 . For those not reporting political violence $p$ equals 0.254 and $1-p$ equals 0.746 . Therefore, the odds ratio is 1.82 , that is, $(0.383 / 0.617) /(0.254 / 0.746)$. A coefficient (odds ratio) higher than 1 indicates an increase in the odds of being interested in politics.
} 
adds the set of sociodemographic controls. Interest in politics increases with age, municipality size and education, and is lower for women. The next column includes 17 regional dummies, which jointly appear highly significant. ${ }^{13}$ Column 4 reports the results from our baseline specification that also includes Nationalists and Republicans. The two new variables significantly increase the probability of being interested in politics, but without affecting the coefficient on political violence, which remains highly significant.

\section{[Insert Table 2 about here]}

The next three columns compare the different types of political violence. Column 5 divides political violence by the identity of the perpetrator (Nationalists, Republicans, and unknown). Interestingly, the effect of political violence is the same when the perpetrators are Republicans or Nationalists (we cannot reject the null hypothesis of equality of coefficients). The effect is not statistically significant when the perpetrators are unknown. This last result suggests that for political violence to have an impact on political attitudes, it is important for information about the traumatic episode to be transmitted within the family. Column 6 distinguishes between severe and moderate political violence, with the effect in both cases being very similar and statistically equal. Finally, column 7 divides political violence into two categories, depending on whether violence is related to military operations or to political repression. The coefficient on violence associated with military operations is slightly higher, but again, we cannot reject the null hypothesis of equality of coefficients.

\section{ROBUSTNESS CHECKS AND THE ENDOGENEITY ISSUE}

\section{Robustness to additional control variables}

Table 3 addresses two concerns about our initial findings. Firstly, the results may be partially due to political repression during Francoism. In this regard, it is important to note that this factor may in fact be considered an intermediate variable. Thus, political violence during the Civil War could affect political attitudes, which could in turn increase the chances of being a victim of political repression during the dictatorship. With this in mind, column 1 controls for an indicator measuring whether the respondent, a relative or someone close suffered political repression during the Francoist dictatorship. The coefficient on repression during Francoism is significantly higher than one, which indicates a greater probability of being interested in

\footnotetext{
${ }^{13}$ The $p$-value of the joint significance test is 0.0006 .
} 
politics, while the coefficient on political violence during the Civil War continues to be statistically highly significant.

\section{[Insert Table 3 about here]}

Secondly, the other concern addressed in Table 3 is that political violence suffered within the family may not be the only major type of violence to be considered. Political violence observed in the local environment (or, in other words, witnessing violence in others) may also matter. Indeed, we can hypothesize opposite effects in both cases. Political violence suffered by the respondent or their family may have positive effects on their interest in politics (as we have observed so far), but political violence in the local environment may diminish the interest in politics. ${ }^{14}$ Column 2 includes the percentage of individuals reporting political violence in the province in which the respondent resides, as a proxy for political violence experienced in the local context. The effect of our main indicator remains fairly similar in size and statistical significance, while the new variable also appears to raise interest in politics. In columns 3 and 4 we calculate analogous variables, albeit referred to the province in which the respondent spent their childhood and adolescence, and to the province in which their parental family lived during the war, respectively. These two variables are statistically insignificant. Column 5 further investigates this question by excluding those observations that report political violence. We then specifically analyze the effect of violence observed in the local environment among those that have not experienced political violence (personally or through their families). Interestingly, the effect of this measure of political violence is now statistically insignificant; with the result being the same using the indicators employed in columns 3 and $4 .^{15}$

\section{Endogeneity concerns}

Table 4 addresses two different endogeneity problems. The first one is related to the subjective nature of our political violence indicator: it refers to what people know or remember. Since individuals interested in politics may be more likely to remember political

\footnotetext{
${ }^{14}$ A past episode of violence can allow politics to feature more in the life of the family, make conversations on politics more frequent, and generate political grievances and resentment, which may lead to political activism. In contrast, families that did not experience violence are not affected by these mechanisms. Instead, witnessing violence in others can create fear and apathy, and the message that it is better not to get involved in politics.

${ }^{15}$ Bellows and Miguel (2009) also provide evidence to show that violence affecting the individual's household is much more relevant than witnessing violence in others.
} 
violence or be more prone to search for information regarding family experiences during the war, the fact of reporting violence in the survey could be endogenous to interest in politics. Although this is a plausible argument, the Civil War was a major historical event that had a profound impact on Spanish families. In some cases, this violent episode was experienced by the respondents themselves, and in the majority of cases by the respondents' parents or grandparents. Therefore, information about violence suffered by the family during the war is quite accessible to everybody (whether or not they are interested in politics), with no need to consciously search for information. In addition, we apply three tests to deal with this issue. Column 1 in Table 4 restricts the sample to older people (aged over 65) under the assumption that they have better information about the past (the war affected them much more directly), and so the potential 'information bias' is lower. Column 2 follows a similar strategy by focusing on respondents that personally suffered political violence during the Civil War. Only individuals aged over 65 were asked whether they personally suffered violence, whereby the sample is trimmed accordingly. This is an interesting test because data on personal victimization are arguably much less affected by the 'information bias'. The odds ratios for political violence in both columns are statistically significant and much higher than 1 , thereby supporting our previous findings.

\section{[Insert Table 4 about here]}

Alternatively, we may argue that severe political violence (e.g., killed in action, murdered, or condemned to death) is more difficult to forget than moderate violence, and that it is easier to be informed about it. Therefore, the 'information bias' can be lower in this case. Column 3 removes observations reporting moderate political violence in order to focus on its severe form, whose coefficient appears statistically highly significant, being very similar to that of the baseline specification. Column 4 applies a different strategy. In this case, we directly control for an indicator measuring the level of information and knowledge of the respondent about the Civil War period. This indicator is estimated as the first principal component of six variables indicating whether the respondent correctly answered several questions about the Civil War (i.e., with an answer other than 'does not know'/ does not answer'). ${ }^{16}$ The

\footnotetext{
${ }^{16}$ Four of these questions are related to the respondent's family situation and experiences during the war period, while the other two refer to the general level of knowledge about the Civil War. Since these are binary variables, we perform the principal component analysis on the polychoric correlation matrix (Kolenikov and Angeles, 2004).
} 
reasoning is as follows: if interest in politics (potentially) leads to a deeper search for information about the war period, we can mitigate this bias by controlling for an indicator measuring the level of knowledge about the war. However, to the extent that being informed about the war may also be the consequence of having a loved one that suffered violence, the inclusion of this indicator may bias the true value of the coefficient on political violence toward zero. Therefore, this is a conservative estimation of the effect of violence on interest in politics. Remarkably, the coefficient on political violence remains statistically significant, although somewhat lower in magnitude, while the new control variable significantly increases the odds of being interested in politics. To recapitulate, the evidence obtained so far in this section suggests that a bias caused by the subjective nature of our indicator is not driving our results.

The second endogeneity problem addressed in Table 4 refers to the omitted variable bias; that is, the existence of other factors affecting both political violence and current political attitudes. In particular, we are concerned with the possibility that families that were politically active before the Civil War could have suffered more political violence as a consequence of their political activism. This, coupled with the fact that political attitudes are transmitted through family socialization, implies that the observed relationship between political violence and current interest in politics may be driven by the family tradition in political attitudes. In other words, what we are observing could be the perpetuation over time of political attitudes within the family.

We address this issue by employing several strategies. In essence, they have to do with controlling for pre-war family political attitudes and focusing on the most exogenous types of political violence. Firstly, the previous regressions have controlled for the variables Republicans and Nationalists, which measure whether the respondent's family sympathized with one or other of the two warring sides. To the extent that these variables of family political identity are related to pre-war political attitudes (e.g., interest in politics), they serve as good controls that allow us to better identify the effect of political violence. Arguably, it is very unlikely that families with no interest at all in politics at the outbreak of the Civil War sympathized with either Nationalists or Republicans. Therefore, by considering this initial political affinity, we partially control for pre-war political attitudes within the family. 
Secondly, we can further mitigate the omitted variable bias by controlling for additional variables capturing the political attitudes of the respondent's family before the outbreak of the war. The survey contains a couple of questions about the parents' political identity in terms of the relevant cleavage during the war, namely, the left-right cleavage. If we restrict the sample to elderly respondents (aged 70 or over), we can create an indicator of family political identity before the war (i.e., the parents' ideology), ${ }^{17}$ and in this way control for a proxy for pre-war political attitudes (to the extent that political attitudes are related to political identities). ${ }^{18}$ Another advantage of using a subsample of respondents over the age of 69 is that, as noted above, we reduce the measurement error in the variables referring to the war period, since elderly people tend to have more direct and better information than young people in this regard.

Column 5 includes the father's political identity, measured by an indicator that takes values from 1 (extreme left) to 10 (extreme right). Column 6 adds the mother's political identity, measured in the same way. The next two columns operationalize political identity in a different way. A linear relationship of political identity in the left-right axis with political violence or political attitudes is probably not satisfactory. Instead, we expect a U-shaped relationship between political identity and our variables of interest; political violence and interest in politics tend to be greater at the extremes of the ideological spectrum. We thus create a new variable, political extremism, taking values from 0 (positions 5 and 6 on the ideological scale) to 4 (positions 1 and 10 on the scale). Column 7 controls for the father's political extremism, and column 8 adds the mother's political extremism. It is remarkable that the coefficient on political violence remains fairly robust to these additions, while the new controls never appear with statistically significant coefficients.

Columns 9 to 11 use an alternative strategy to deal with this endogeneity issue by focusing on the most exogenous types of political violence (with respect to pre-war political attitudes). Some types of political violence are probably more closely associated with pre-war political

\footnotetext{
${ }^{17}$ Individuals aged 70 in 2008 (year of the survey) were born in 1938. Assuming that on average the parents of these respondents were 30 years old when these were born, then at the outbreak of the Civil War they were 28 years old (the average age of childbirth is generally considered to be 30 -usually referred to as 'generational duration'-, with this age remaining relatively stable over time [Piketty, 2014, Ch. 11]). If we assume that political identity is already shaped by the age of 28 (which is a reasonable assumption -see Rubin et al., 1998, and references therein), we can thus create an indicator of the pre-war parents' ideology.

${ }^{18}$ Using current data, there is indeed a strong link between interest in politics and an indicator of political identity such as political extremism (see the definition of this variable below).
} 
activism than others. This is the case of the categories previously labeled as political repression (e.g., murdered, condemned to death or imprisoned -see Section 4.1), which were probably more concentrated on political party members and people publicly identified with one of the political factions. In contrast, the categories related to military operations, that is, killed in action and died in bombing, are more randomly distributed. As argued in Balcells (2012), there is some randomness in the initial areas under the control of each faction, and both armies enforced military conscription. Thus, certain exogeneity exists regarding who fought in the war. Column 9 compares the effect of violence due to military operations with that of no political violence at all; that is, the sample excludes individuals reporting political repression. It is reassuring that the coefficient on political violence remains largely similar to that of our baseline specification, which is totally consistent with the result shown in Table 2 (column 7), where we indicate that the coefficients on violence due to repression and military operations are statistically equal.

Column 10 focuses on bombing, which is by nature the most randomly distributed type of violence. In this specification, the treatment group is composed of those individuals reporting that a relative or someone close died in a bombing, and the comparison group consists of respondents not reporting violence. A drawback of this approach is the small number of observations that report bombing (only 64), but it is still pertinent to check whether the effect on the interest in politics remains. Remarkably, the odds of being interested in politics are about $73 \%$ higher for those reporting bombing than for those not reporting violence, with the difference being statistically significant.

A similar strategy is conducted in column 11. It has been argued that political violence perpetrated by the Nationalists was more systematic than that perpetrated by the Republicans. Herreros and Criado (2009) argue that in the territory under their control, the Nationalists concentrated violence on individuals that could have acted as political leaders in any opposition to Francoist rule. Consequently, leftist and Republican political activists were more severely persecuted. In contrast, according to these authors, political violence conducted in the Republican zone did not follow this logic, but instead was due to the collapse of the state, and had a more indiscriminate character. This implies that Republican violence was more randomly distributed than Nationalist repression and, therefore, constitutes a more exogenous variable of political violence. Accordingly, column 11 focuses on respondents 
reporting violence perpetrated by the Republicans, and shows that the effect is very similar to that observed in the baseline specification. Indeed, column 5 in Table 2 shows that the coefficients on Nationalist and Republican political violence are statistically equal. All this evidence suggests that systematic selection into victimization is not driving the results. ${ }^{19}$

To sum up, the political violence suffered by the respondents or their families during the Civil War appears to exert an important impact on current political attitudes. Using the whole sample, the odds of being interested in politics are at least $50 \%$ higher for individuals reporting political violence. Using subsamples of older people, the odds are more than $100 \%$ higher. The results are robust to controlling for a wide array of factors and to several endogeneity tests. The consistency recorded by the coefficient on political violence suggests that the findings are not an artifact due to a problem of endogeneity.

\section{SOME EVIDENCE ABOUT THE MECHANISMS}

Thus far we have shown that political violence has a long-term positive effect on interest in politics. We hold the view that two mechanisms are at work. Firstly, political violence affects political attitudes and behaviors, for example, through grievances and resentment or by making politics more present in the life of the family. All these factors can increase interest in politics. ${ }^{20}$ Secondly, political attitudes are transmitted within the family from one generation to the next. Table 5 provides some evidence consistent with these hypotheses.

We begin with the second point. The persistence of the effect over time indicates that family socialization is a key mechanism. It is striking that an event that happened seventy years ago

\footnotetext{
${ }^{19}$ The effect of political violence also remains after excluding from the sample respondents whose families had affinity with one of the two sides in the war (in this way, we exclude individuals from politically active families). Moreover, the results are robust when simultaneously addressing the two endogeneity problems indicated above. In this sense, we have conducted the following tests: 1) to control at the same time for the father's extremism and the level of knowledge about the war, 2) to focus on the most exogenous types of violence, and to either control for our indicator of knowledge about the war or restrict the sample to respondents older than 65 . These results are available in the Supporting Information.

${ }^{20}$ This argument and our results in general are related to psychology research that finds evidence of positive responses to trauma. Children victims of violence or other traumas are in general resilient, with results suggesting that resilience usually emerges from the normative functions of human adaptational systems (Masten, 2001). Findings of 'post-traumatic growth' experiences (i.e., positive changes occurring as a consequence of a struggle with a severe life crisis) prevail over those of psychiatric disorders (Tedeschi and Calhoun, 2004). For example, Carmil and Breznitz (1991) find that Holocaust survivors and children of survivors have less extreme political preferences, greater belief in God, and are more optimistic about the future, while Punamäki et al. (1997) find a positive correlation between traumatic events and children's political activity. More recently, Annan et al. (2011) argue that although war and violence generate social and psychological problems, particularly in females, the majority of ex-combatants are resilient and able to reintegrate socially.
} 
continues to shape political attitudes today, even among people that had not yet been born. To make it absolutely clear that political violence during the war affects people that did not experience it, the first two columns in Table 5 divide the sample by the median age of 45 . The coefficient on political violence for respondents under the age of 45 (column 2) -who were born well after the war- is very similar to the coefficient for those aged 45 or over (column 1); indeed, it is slightly greater. Column 3 shows that the effect of political violence remains unchanged even when restricting the sample to the young (up to the age of 30).

A more direct way to analyze the role of family socialization is conducted in columns 4 and 5, where the dependent variables are whether the respondent's family used to talk about the Civil War during his or her childhood and adolescence, and whether the respondent was often exposed to conversations on politics at home, respectively. Interestingly, our indicator of political violence significantly increases the probability of family conversations about the war and political conversations at home. In the first case, the odds ratio is higher, which suggests that political violence specifically increases the frequency of conversations about the war and, generally, conversations about politics at home.

\section{[Insert Table 5 about here]}

Regarding the first mechanism mentioned above, column 6 analyzes whether political violence is related to a feeling of rage when thinking about the Civil War. According to our argument, political violence leads to rage or resentment, and then to political activism. This is exactly what we observe: the coefficient on political violence is higher than 1 and statistically significant. Column 7 uses the dependent variable of whether thinking about the war produces a feeling of fear. This exercise is a falsification test, since we do not expect political violence to be associated with such a feeling. Indeed, the feeling of fear is related to the common expectation of a negative effect of civil conflicts on public engagement, in the sense that political violence leads to fear, and fear leads to political apathy. As predicted by our argument, the coefficient on political violence is statistically insignificant in this case.

The last column tests whether political violence has an effect on a respondent's political extremism (measured in the same way as 'father's extremism'). Although we do not make specific predictions about this question, this is an interesting issue to analyze. We find that past political violence is not related to current political extremism, which suggests that it does not work as an intervening variable. This result is encouraging from the point of view of 
conflict resolution, which is in line with the findings reported by Blattman (2009) on the very different context of Uganda, where violence led to peaceful and productive participation. ${ }^{21}$

\section{OTHER INDICATORS OF POLITICAL ATTITUDES}

Table 6 reports the results from our baseline specification for other indicators of political attitudes, knowledge and engagement. We begin with an indicator that reflects the respondent's view about the role of politics in society, in particular, whether politics only creates conflicts and divisions. Such a negative view about politics is clearly related to political apathy. Secondly, column 2 uses an indicator measuring whether the respondent considers that it is very important to be informed about politics. Next, we introduce three variables related to the individual's channels for obtaining political information (columns 35). They stand for how often the respondent reads the political sections in newspapers, listens to or watches the news, and uses the Internet to obtain political information, respectively, with values ranging from 0 (never) to 4 (daily). The three previous indicators are complemented by an indicator on actual political knowledge (column 6). It is created by combining the answers to three questions about Spanish political issues. The scale of this indicator ranges from 0 (all wrong answers) to 3 (all correct answers).

\section{[Insert Table 6 about here]}

The next set of variables involves the attitudes and behaviors related to political participation. Column 7 introduces an indicator reflecting political apathy: 'it is better not to get involved in politics'; while column 8 uses a variable that indicates a favorable opinion about political participation: whether the respondent agrees with the statement whereby for democracy to work well, citizens must participate in politics. Columns 9 and 10 employ two variables measuring whether the respondent has in the last year or ever taken part in any one of the following actions: writing to the press to complain, contacting public officials, participating in a strike or demonstration, or signing a petition. Finally, column 11 uses a variable indicating whether the individual voted in the last parliamentary elections. Specifications using dichotomous dependent variables are estimated with a logistic regression model, while equations that use non-dichotomous variables are estimated via OLS.

\footnotetext{
21 The indicators Civil War conversations, Political conversations, Thinking about the Civil War: Rage and Political extremism are positively and significantly related to interest in politics. The odds ratios are particularly high for the first two variables. Thinking about the Civil War: Fear has a negative impact on interest in politics. These unreported results are available in the Supporting Information.
} 
The results are fully consistent with our previous findings. On the one hand, political violence reduces the probability of considering that politics only creates conflicts, and of thinking that 'it is better not to get involved in politics'. On the other hand, political violence increases the frequency of using the mass media and the Internet to obtain political information, real political knowledge, the likelihood of thinking that political participation is important for democracy, and real engagement in politics (except in the case of voting) ${ }^{22}$ Therefore, the long-term consequences of political violence, far from creating political apathy, are a higher level of interest in politics, more public involvement, and a more favorable view of the political process.

\section{CONCLUSIONS}

This paper shows that the Spanish Civil War continues to influence the political attitudes of citizens today. Preliminary cross-province evidence suggests that political repression perpetrated during the war is positively correlated with current electoral turnout. A more comprehensive analysis using survey data indicates a positive effect of political violence on interest in politics, as well as on other indicators of political attitudes, knowledge and engagement. The effect of political violence appears remarkably robust, remaining after controlling for many individual characteristics, regional fixed-effects, and variables referred to the war period. The analysis also addresses two endogeneity problems: one related to the fact that those individuals with a greater interest in politics may have better information about the past and report more violence; and the other related to the possibility that politically active families could have suffered more violence during the war. A battery of tests suggests that endogeneity is not driving the results, although we are aware that it is impossible to completely rule out a potential endogeneity bias.

A long-term positive effect of political violence on political participation is a heartening result, particularly considering that Spain experienced a long dictatorship after the war. Our results are consistent with the findings of other papers that analyze the short-term effects of political violence on political participation in developing countries (Bellows and Miguel, 2009, Blattman, 2009, Gilligan et al., 2014). We argue that family socialization plays a central role in transmitting the effect of political violence. In this regard, individuals from

\footnotetext{
22 The odds ratio for voting is higher than 1 , but statistically insignificant. The reason may be the low variability in the answers to this question (only $15 \%$ of respondents indicate abstention).
} 
families that suffered political violence were more exposed to conversations on politics at home during their childhood and adolescence. In addition, our results suggest that the current lack of interest in politics in Spain does not have its roots in the extreme political violence experienced by Spanish society during the Civil War. Contrary to expectations, the war appears to have left a positive legacy on attitudes toward political participation.

This article is also related to the literature on the historical determinants of culture. Our analysis indicates that a historical event that occurred seventy years ago is an important determinant of attitudes towards political participation, and therefore of social capital. Given the importance attributed to social capital for the proper functioning of the economy and democracy (e.g., Knack and Keefer, 1997; Putnam et al., 1993), it is an encouraging result that political violence does not necessarily undermine it.

\section{REFERENCES}

Abella, Rafael (1976). La Vida Cotidiana Durante la Guerra Civil. Barcelona: Planeta.

Aguilar, Paloma, Laia Balcells and Héctor Cebolla-Boado (2011). Determinants of Attitudes Toward Transitional Justice: An Empirical Analysis of the Spanish Case, Comparative Political Studies. 44: 1397-1430.

Alesina, Alberto and Paola Giuliano (2011). Family Ties and Political Participation, Journal of the European Economic Association. 9: 817-839.

Alesina, Alberto and Paola Giuliano (2015). Culture and Institutions, forthcoming in Journal of Economic Literature.

Anderson, Christopher J. and Yuliya V. Tverdova (2003). Corruption, Political Allegiances, and Attitudes Toward Government in Contemporary Democracies, American Journal of Political Science. 47: 91-109.

Angrist, Joshua D. and Jörn-Steffen Pischke (2009). Mostly Harmless Econometrics: An Empiricist's Companion. Princeton: Princeton University Press.

Annan, Jeannie, Christopher Blattman, Dyan Mazurana and Khristopher Carlson (2011). Civil War, Reintegration, and Gender in Northern Uganda, Journal of Conflict Resolution. 55: 877-908.

Balcells, Laia (2012). The Consequences of Victimization on Political Identities: Evidence from Spain, Politics \& Society. 40: 311-347. 
Balcells, Laia and Patricia Justino (2014). Bridging Micro and Macro Approaches on Civil Wars and Political Violence: Issues, Challenges, and the Way Forward, Journal of Conflict Resolution. 58: 1-17.

Beber, Bernd, Philip Roessler and Alexandra Scacco (2014). Intergroup Violence and Political Attitudes: Evidence from a Dividing Sudan, The Journal of Politics. 76: 649-665.

Beevor, Antony (2006). The Battle for Spain: The Spanish Civil War 1936-1939. London: Weidenfeld \& Nicolson.

Bellows, John and Edward Miguel (2009). War and Local Collective Action in Sierra Leone, Journal of Public Economics. 93: 1144-1157.

Blattman, Christopher (2009). From Violence to Voting: War and Political Participation in Uganda, American Political Science Review. 103: 231-247.

Blattman, Christopher and Edward Miguel (2010). Civil War, Journal of Economic Literature. 48: 3-57.

Carmil, Devora and Shlomo Breznitz (1991). Personal Trauma and World View-Are Extremely Stressful Experiences Related to Political Attitudes, Religious Beliefs, and Future Orientation?, Journal of Traumatic Stress. 4: 393-405.

Carreras, Albert, Leandro Prados de la Escosura and Joan R. Rosés (2005). Renta y Riqueza, in: Albert Carreras and Xavier Tafunell (eds.), Estadísticas Históricas de España. Siglos XIX-XX. Bilbao: Fundación BBVA: 1297-1376.

CIS (2008). Estudio: 2760. Memorias de la Guerra Civil y el Franquismo, Centro de Investigaciones Sociológicas, http://www.cis.es/.

Collier, Paul, Lani Elliott, Håvard Hegre, Anke Hoeffler, Marta Reynal-Querol and Nicholas Sambanis (2003). Breaking the Conflict Trap: Civil War and Development Policy. Washington, DC: World Bank and Oxford University Press.

Espinosa-Maestre, Francisco (2008). Informe sobre la Represión Franquista. Estado de la Cuestión, Report prepared for the Preliminary Investigations 399/2006-E, Central Court of Instruction number 5, Madrid.

García de Cortázar, Fernando (2005). Atlas de Historia de España. Barcelona: Planeta.

Gates, Scott, Håvard Hegre, Håvard M. Nygård and Håvard Strand (2012). Development Consequences of Armed Conflict, World Development. 40: 1713-1722.

Gilligan, Michael J., Benjamin J. Pasquale and Cyrus Samii (2014). Civil War and Social Cohesion: Lab-in-the-Field Evidence from Nepal, American Journal of Political Science. 58: 604-619. 
Guiso, Luigi, Paola Sapienza and Luigi Zingales (2006). Does Culture Affect Economic Outcomes?, Journal of Economic Perspectives. 20: 23-48.

Guiso, Luigi, Paola Sapienza and Luigi Zingales (2008). Long Term Persistence, National Bureau of Economic Research, Working Paper 14278.

Herreros, Francisco and Henar Criado (2009). Pre-emptive or Arbitrary: Two Forms of Lethal Violence in a Civil War, Journal of Conflict Resolution. 53: 419-445.

ISSP (2004). International Social Survey Programme 2004: Citizenship (ISSP 2004), http://www.issp.org/.

IVIE (2012). Human Capital Data, Instituto Valenciano de Investigaciones Económicas, http://www.ivie.es/ (Accessed October 4, 2012).

Juliá, Santos, Julián Casanova, Josep M. Solé, Joan Villarroya and Francisco Moreno (1999). Víctimas de la Guerra Civil. Madrid: Temas de Hoy.

Knack, Stephen and Philip Keefer (1997). Does Social Capital Have an Economic Payoff? A Cross-Country Investigation, The Quarterly Journal of Economics. 112: 1251-1288.

Kolenikov, Stanislav and Gustavo Angeles (2004). The Use of Discrete Data in Principal Component Analysis With Applications to Socio-Economic Indices, CPC/MEASURE Working paper No. WP-04-85.

Linz, Juan J. and Jesus M. De Miguel (1977). Hacia un Análisis Regional de las Elecciones de 1936 en España, Revista Española de la Opinión Pública. 48: 27-68.

Lipset, Seymour M. (1959). Some Social Requisites of Democracy: Economic Development and Political Legitimacy, American Political Science Review. 53: 69-105.

Masten, Ann S. (2001). Ordinary Magic: Resilience Processes in Development, American Psychologist. 56: 227-38.

Ministerio del Interior (2014). Resultados Electorales. Ministerio del Interior, Gobierno de España, http://www.interior.gob.es/ (Accessed June 11, 2014).

Nunn, Nathan (2012). Culture and the Historical Process, Economic History of Developing Regions. 27:108-126.

Piketty, Thomas (2014). Capital in the Twenty-First Century. Massachusetts, U.S.: Harvard University Press.

Preston, Paul (2006). The Spanish Civil War: Reaction, Revolution and Revenge. London: Harper Perennial. 
Punamäki, Raija-Leena, Samir Qouta and Eyad El Sarraj (1997). Relationships between Traumatic Events, Children's Gender, and Political Activity, and Perceptions of Parenting Styles, International Journal of Behavioral Development. 21: 91-109.

Puntscher, Sibylle, Christoph Hauser, Karin Pichler and Gottfried Tappeiner (2014). Social Capital and Collective Memory: A Complex Relationship, Kyklos. 67: 116-132.

Putnam, Robert, Robert Leonardi and Raffaella Nanetti (1993). Making Democracy Work. Civic Traditions in Modern Italy. New York: Simon \& Schuster.

Rohrschneider, Robert (2005). Institutional Quality and Perceptions of Representation in Advanced Industrial Democracies, Comparative Political Studies. 38: 850-874.

Rubin, David C., Tamara A. Rahhal and Leonard W. Poon (1998). Things Learned in Early Adulthood Are Remembered Best, Memory \& Cognition. 26: 3-19.

Sabatini, Fabio (2008). Social Capital and the Quality of Economic Development, Kyklos. 61: 466-499.

Tedeschi, Richard G. and Lawrence G. Calhoun (2004). Posttraumatic Growth: Conceptual Foundations and Empirical Evidence, Psychological Inquiry. 15: 1-18.

Thomas, Hugh (2001). The Spanish Civil War: Revised Edition. New York: Modern Library.

Toya, Hideki and Mark Skidmore (2014). Do Natural Disasters Enhance Societal Trust?, Kyklos. 67: 255-279.

Welsch, Heinz (2008). The Social Costs of Civil Conflict: Evidence from Surveys of Happiness, Kyklos. 61: 320-340.

World Bank (2011). World Development Report: Conflict, Security, and Development. Washington, D.C: The World Bank. 


\section{TABLES}

Table 1

Political violence and political participation: Cross-province evidence

Dependent variable is Electoral turnout (1977-2011)

\begin{tabular}{|c|c|c|c|c|c|c|c|}
\hline & 1 & 2 & 3 & 4 & 5 & 6 & 7 \\
\hline Francoist political repression & $\begin{array}{l}0.313 * \\
(0.166)\end{array}$ & $\begin{array}{l}0.42 * * \\
(0.178)\end{array}$ & $\begin{array}{c}0.389 * * \\
(0.178)\end{array}$ & $\begin{array}{l}0.424 * * \\
(0.182)\end{array}$ & & & \\
\hline Republican political repression & & & & & $\begin{array}{c}0.73 * \\
(0.388)\end{array}$ & $\begin{array}{l}-0.272 \\
(0.379)\end{array}$ & $\begin{array}{l}-0.181 \\
(0.392)\end{array}$ \\
\hline $\begin{array}{l}\text { Dummy- Francoist political } \\
\text { repression partially investigated }\end{array}$ & $\begin{array}{l}3.381 * \\
(1.781)\end{array}$ & $\begin{array}{c}2.648 * * \\
(1.141)\end{array}$ & $\begin{array}{c}1.695 \\
(1.159)\end{array}$ & & & & \\
\hline Left vote $(\%)$ in 1936 & & $\begin{array}{l}-0.067 \\
(0.064)\end{array}$ & $\begin{array}{l}-0.069 \\
(0.066)\end{array}$ & $\begin{array}{l}-0.087 \\
(0.077)\end{array}$ & & $\begin{array}{l}-0.009 \\
(0.072)\end{array}$ & $\begin{array}{l}-0.016 \\
(0.07)\end{array}$ \\
\hline Electoral turnout (\%) in 1936 & & $\begin{array}{l}0.366 * * * \\
(0.118)\end{array}$ & $\begin{array}{l}0.372 * * * \\
(0.121)\end{array}$ & $\begin{array}{l}0.366^{* * * *} \\
(0.124)\end{array}$ & & $\begin{array}{c}0.373 * * \\
(0.16)\end{array}$ & $\begin{array}{l}0.373 * * \\
(0.157)\end{array}$ \\
\hline Successful coup & & $\begin{array}{l}3.945^{*} \\
(2.087)\end{array}$ & $\begin{array}{l}3.895^{*} \\
(2.043)\end{array}$ & $\begin{array}{l}4.478 * \\
(2.438)\end{array}$ & & $\begin{array}{c}2.354 \\
(2.492)\end{array}$ & $\begin{array}{c}2.449 \\
(2.322)\end{array}$ \\
\hline Days under Republican control & & $\begin{array}{c}0.008 * * * \\
(0.003)\end{array}$ & $\begin{array}{c}0.009 * * * \\
(0.003)\end{array}$ & $\begin{array}{c}0.01 * * * \\
(0.003)\end{array}$ & & $\begin{array}{c}0.005 \\
(0.003)\end{array}$ & $\begin{array}{c}0.006 * * \\
(0.003)\end{array}$ \\
\hline Per capita GDP in 1981 & & & $\begin{array}{c}-6.23 \\
(4.571)\end{array}$ & $\begin{array}{c}-6.92 \\
(4.851)\end{array}$ & & & $\begin{array}{c}-10.178 * \\
(5.195)\end{array}$ \\
\hline Education in 1980 & & & $\begin{array}{l}0.049 \\
(0.18)\end{array}$ & $\begin{array}{c}0.058 \\
(0.217)\end{array}$ & & & $\begin{array}{c}0.214 \\
(0.198)\end{array}$ \\
\hline$R^{2}$ & 0.11 & 0.51 & 0.53 & 0.50 & 0.08 & 0.35 & 0.43 \\
\hline Number of observations & 48 & 46 & 46 & 40 & 36 & 34 & 34 \\
\hline
\end{tabular}

Notes: Variables descriptions are provided in Appendix I. All regressions are estimated by OLS. The estimations include a constant term, which is omitted for space considerations. Robust standard errors are in parentheses. *, ** and $* * *$ denote significance at the 10,5 and $1 \%$ level, respectively. 
Table 2

Political violence and political attitudes: Survey evidence (logistic regressions reporting odds ratios)

Dependent variable is Interest in politics

\begin{tabular}{|c|c|c|c|c|c|c|c|}
\hline & 1 & 2 & 3 & 4 & 5 & 6 & 7 \\
\hline Political violence & $1.824 * * *$ & $1.668 * * *$ & $1.736^{* * *}$ & $1.522 * * *$ & & & \\
\hline Pol. violence perpetrated by Nationalists & & & & & $1.742 * * *$ & & \\
\hline Pol. violence perpetrated by Republicans & & & & & $1.801 * * *$ & & \\
\hline Pol. violence: unknown perpetrators & & & & & 0.909 & & \\
\hline
\end{tabular}

Severe political violence

Moderate political violence

Moderate political violence

Violence related to political repression

Violence related to military operations

Age

Woman

Religiosity

Size of municipality

Secondary education

Higher education

Family affinity with Nationalists

Family affinity with Republicans

Regional dummies

Pseudo- $R^{2}$

Number of observations

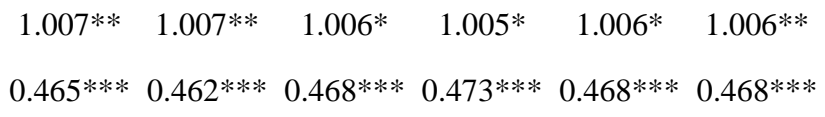

$\begin{array}{llllll}1.023 & 1.015 & 1.023 & 1.025 & 1.023 & 1.023\end{array}$

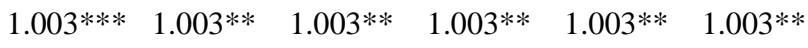

$2.298 * * * 2.363 * * * 2.345 * * * 2.306 * * * 2.346 * * * 2.349 * * *$

4.844*** $4.983 * * * 4.966 * * * 4.786 * * * 4.965 * * * 4.967 * * *$

$$
1.775 * * * 1.681 * * * 1.775 * * * 1.767 * * *
$$$$
1.898 * * * 1.699 * * * 1.898 * * * 1.901 * * *
$$

Notes: Variables descriptions are provided in Appendix I. All regressions are estimated by a logistic regression model reporting odds ratios. The estimations include a constant term, which is omitted for space considerations. *, ** and *** denote significance at the 10, 5 and $1 \%$ level, respectively. Significance levels are estimated using robust standard errors. 
Table 3

Political violence and political attitudes: Robustness to additional controls (logistic regressions reporting odds ratios)

Dependent variable is Interest in politics

\begin{tabular}{|c|c|c|c|c|c|}
\hline & 1 & 2 & 3 & 4 & $\begin{array}{l}\text { Individuals reporting } \\
\text { political violence } \\
\text { removed } \\
5\end{array}$ \\
\hline 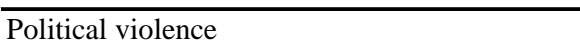 & $1.447 * * *$ & $1.465 * * *$ & $1.504 * * *$ & $1.508 * * *$ & \\
\hline Age & 1.005 & $1.006^{*}$ & $1.006^{*}$ & $1.006^{*}$ & $1.009^{*}$ \\
\hline Woman & $0.47 * * *$ & $0.468 * * *$ & $0.467 * * *$ & $0.467 * * *$ & $0.455^{* * *}$ \\
\hline Religiosity & 1.021 & 1.023 & 1.023 & 1.023 & 0.998 \\
\hline Size of municipality & $1.003 * *$ & $1.003 * * *$ & $1.003^{* *}$ & $1.003^{* *}$ & 1.002 \\
\hline Secondary education & $2.28 * * *$ & $2.325 * * *$ & $2.345^{* * *}$ & $2.342 * * *$ & $2.148 * * *$ \\
\hline Higher education & $4.931 * * *$ & $4.943 * * *$ & $4.97 * * *$ & $4.962 * * *$ & $4.103 * * *$ \\
\hline Family affinity with Nationalists & $1.853 * * *$ & $1.79 * * *$ & $1.775^{* * *}$ & $1.777 * * *$ & $1.963 * * *$ \\
\hline Family affinity with Republicans & $1.983 * * *$ & $1.929 * * *$ & $1.9 * * *$ & $1.896 * * *$ & $2.023 * * *$ \\
\hline Repression during Francoism & $1.313^{* *}$ & & & & \\
\hline Average political violence: current province & & $1.008^{*}$ & & & 1.004 \\
\hline Average political violence: childhood province & & & 1.002 & & \\
\hline Average political violence: Civil War province & & & & 1.002 & \\
\hline Regional dummies & Yes & Yes & Yes & Yes & Yes \\
\hline Pseudo- $R^{2}$ & 0.13 & 0.13 & 0.12 & 0.12 & 0.11 \\
\hline Number of observations & 2,336 & 2,532 & 2,532 & 2,532 & 1,322 \\
\hline
\end{tabular}

Notes: Variables descriptions are provided in Appendix I. All regressions are estimated by a logistic regression model reporting odds ratios. The estimations include a constant term, which is omitted for space considerations. *, ** and *** denote significance at the 10,5 and $1 \%$ level, respectively. Significance levels are estimated using robust standard errors. 


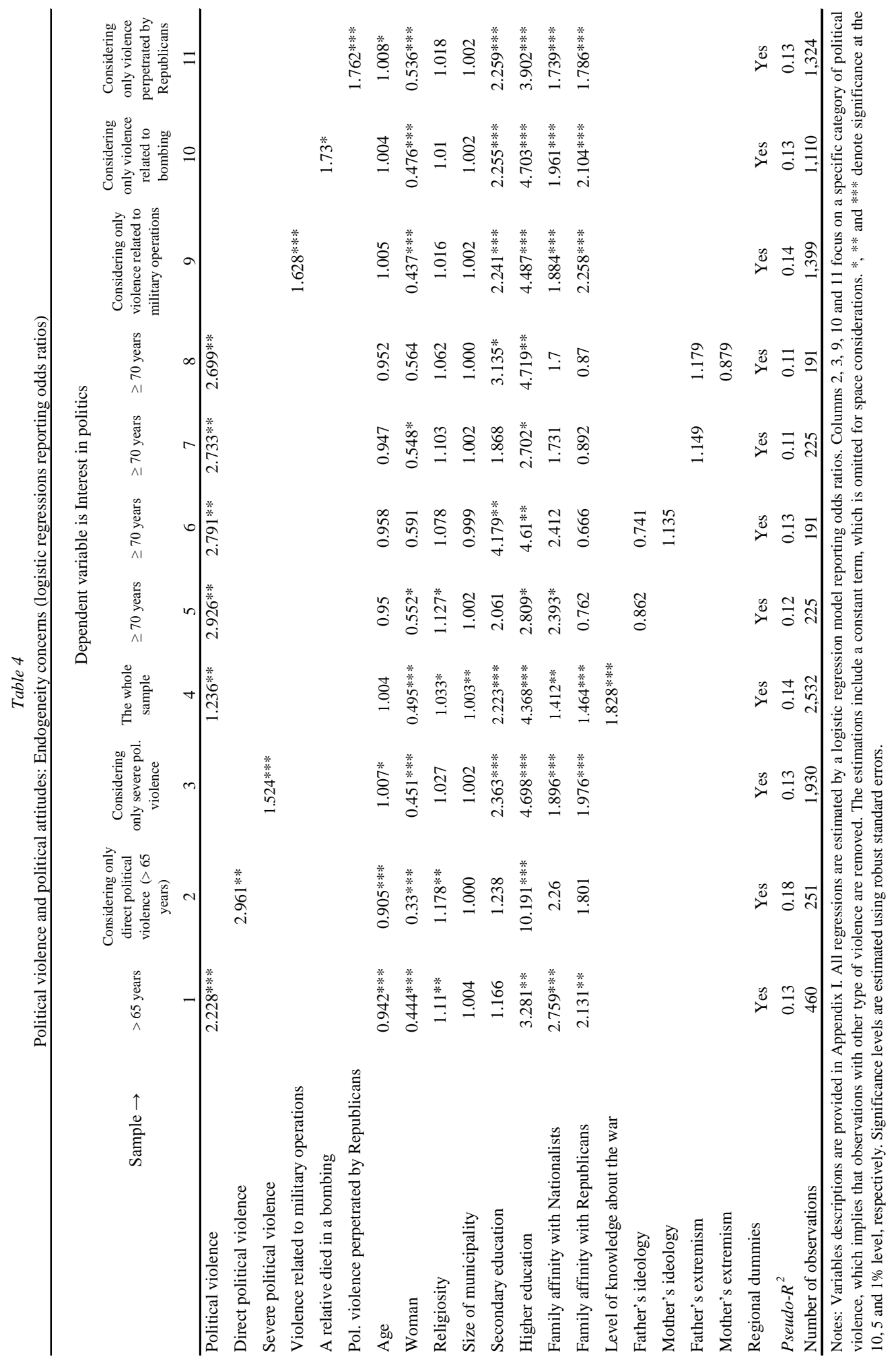


Table 5

Potential mechanisms by which political violence affects political attitudes (logistic regressions reporting odds ratios)

\begin{tabular}{|c|c|c|c|c|c|c|c|c|}
\hline \multirow[t]{3}{*}{ Dependent variable $\rightarrow$} & \multicolumn{3}{|c|}{ Interest in politics } & \multirow{2}{*}{$\begin{array}{l}\text { Civil War } \\
\text { conversa- } \\
\text { tions }\end{array}$} & \multirow{2}{*}{$\begin{array}{l}\text { Political } \\
\text { conversa- } \\
\text { tions }\end{array}$} & \multirow{2}{*}{$\begin{array}{c}\text { Thinking about } \\
\text { the Civil War: } \\
\text { Rage }\end{array}$} & \multirow{2}{*}{$\begin{array}{c}\text { Thinking about } \\
\text { the Civil War: } \\
\text { Fear }\end{array}$} & \multirow{2}{*}{$\begin{array}{l}\text { Political } \\
\text { extremism }\end{array}$} \\
\hline & ( $\geq 45$ years) & $(<45$ years $)$ & $(\leq 30$ years $)$ & & & & & \\
\hline & 1 & 2 & 3 & 4 & 5 & 6 & 7 & 8 \\
\hline Political violence & $1.459^{* * *}$ & $1.532 * * *$ & $1.55^{*}$ & $2.275^{* * *}$ & $1.823 * * *$ & $1.177^{*}$ & 1.04 & 0.936 \\
\hline Age & $0.98 * * *$ & 1.01 & 0.962 & $1.019 * * *$ & $0.983 * * *$ & $1.007 * *$ & 1.001 & 1.002 \\
\hline Woman & $0.444 * * *$ & $0.464 * * *$ & $0.537 * * *$ & $1.245 * *$ & 0.913 & 1.074 & $1.431 * * *$ & 0.976 \\
\hline Religiosity & 1.004 & $1.055^{* *}$ & 1.012 & 0.996 & 1.01 & $0.96 * * *$ & 1.025 & $0.89 * * *$ \\
\hline Size of municipality & $1.004 * *$ & 1.003 & 1.002 & 1.00 & $1.004 * * *$ & $0.998^{*}$ & 0.999 & 1.001 \\
\hline Secondary education & $2.068 * * *$ & $2.624 * * *$ & $2.243 * * *$ & 1.22 & $1.464 * * *$ & 1.059 & 0.841 & 1.01 \\
\hline Higher education & $4.839 * * *$ & $5.668 * * *$ & $5.801 * * *$ & $1.598 * * *$ & $2.567 * * *$ & 1.05 & $0.683^{* *}$ & 1.002 \\
\hline $\begin{array}{l}\text { Family affinity with } \\
\text { Nationalists }\end{array}$ & $2.309 * * *$ & 1.322 & 0.777 & $1.617 * * *$ & $1.676^{* * * *}$ & 0.82 & 0.862 & $1.522 * * *$ \\
\hline $\begin{array}{l}\text { Family affinity with } \\
\text { Republicans }\end{array}$ & $1.986 * * *$ & $1.753 * * *$ & $1.661 * *$ & $1.954 * * *$ & $2.186^{* * *}$ & $1.437 * * *$ & 1.013 & $2.688 * * *$ \\
\hline Regional dummies & Yes & Yes & Yes & Yes & Yes & Yes & Yes & Yes \\
\hline Pseudo- $R^{2}$ & 0.16 & 0.13 & 0.14 & 0.08 & 0.10 & 0.02 & 0.02 & 0.08 \\
\hline Number of observations & 1,245 & 1,287 & 534 & 2,470 & 2,479 & 2,533 & 2,520 & 2,146 \\
\hline
\end{tabular}




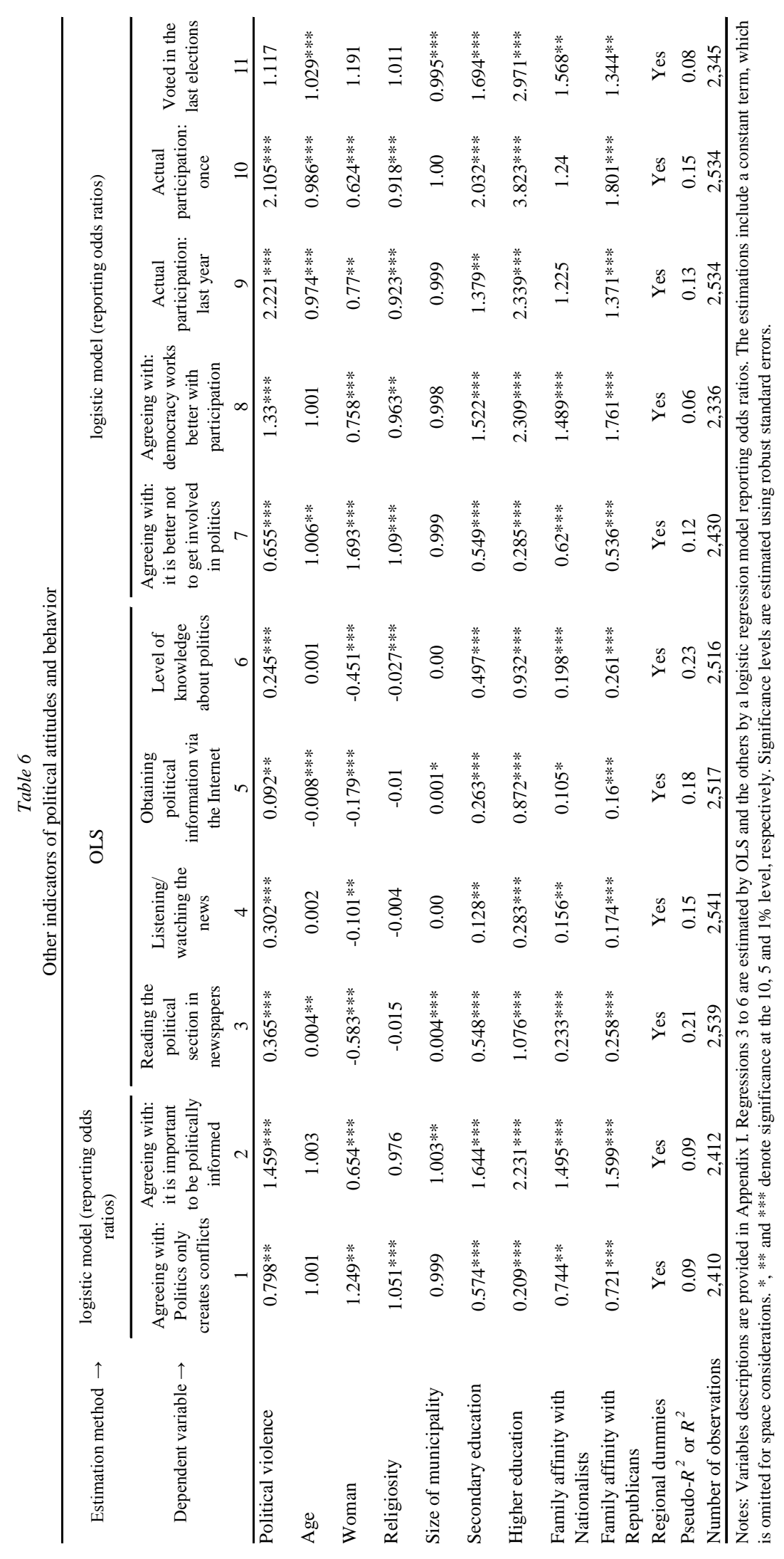




\section{APPENDIX I}

Description of variables

\begin{tabular}{cc}
\hline Variable & Description \\
\hline
\end{tabular}

\section{Cross-province data}

Electoral turnout (19772011)

Francoist political repression, Republican political repression

Dummy- Francoist political repression partially investigated

Left vote (\%) in 1936

Electoral turnout (\%) in 1936

Successful coup

Days under Republican control

Per capita GDP in 1981

Education in 1980

\section{Survey data: ${ }^{1}$}

Main dependent variable Interest in politics

\section{Political violence variables}

Political violence

This is the main indicator of political violence: dummy variable reflecting whether the respondent, a relative or someone close suffered political violence during the Civil War. With respect to violence suffered by a relative or someone close, the survey asks for up to three people. We only focus on the first person. This also applies to the following indicators of political violence.

Pol. violence perpetrated by Nationalists, Republicans or unknown perpetrators

Severe political violence, Moderate political violence

Average electoral turnout (actual voters/electoral census) of all the parliamentary elections held in Spain since 1977 (Electoral results, Ministerio del Interior, 2014).

The ratio of deaths due to Francoist/Republican political repression to total population in 1930, in thousands (Juliá et al., 1999; Espinosa-Maestre, 2008; 1930 Population Census, Instituto Nacional de Estadística -INE-, http://www.ine.es/).

Dummy variable indicating whether the province has been only partially investigated with respect to data on Francoist political repression. There are six provinces only partially investigated (Juliá et al., 1999; Espinosa-Maestre, 2008).

Percentage of votes obtained by the left-wing coalition in the last parliamentary elections held in the Second Republic, in February 1936 (Linz and De Miguel, 1977).

Electoral turnout in the last parliamentary elections held in the Second Republic, in February 1936 (Linz and De Miguel, 1977).

Dummy variable indicating whether the military coup succeeded in the capital city of the province. For the case of Asturias, we consider whether the military coup succeeded in Gijón, the most populated city (García de Cortázar, 2005).

Number of days (since the coup) that the province remained under Republican control (Abella, 1976).

GDP per capita in 1981 (Carreras et al., 2005).

Percentage of individuals with secondary or higher education over the total working age population -aged 16 or older (Human capital data, IVIE, 2012).

Dummy variable indicating whether the individual is very or fairly interested in politics.

Three dummy variables indicating whether the respondent, a relative or someone close suffered political violence during the Civil War perpetrated by Nationalists (Francoists), Republicans, or the perpetrators are unknown (the respondent answers DK/NA).

Two dummy variables reflecting whether a relative or someone close suffered severe political violence during the Civil War (killed in action, died in bombing, murdered, condemned to death, disappeared, forced into exile) or moderate political violence (imprisoned, forced into hiding, fired from work, and other situations). Political violence suffered by the actual respondent is coded as severe political violence. 
Description of variables (Continued)

\begin{tabular}{|c|c|}
\hline Variable & Description \\
\hline $\begin{array}{l}\text { Violence related to military } \\
\text { operations or political } \\
\text { repression }\end{array}$ & $\begin{array}{l}\text { Two dummy variables indicating whether a relative or someone close suffered political violence } \\
\text { during the Civil War that can be associated with military operations (killed in action or died in } \\
\text { bombing) or with political repression (the other categories). }\end{array}$ \\
\hline A relative died in a bombing & $\begin{array}{l}\text { Dummy variable reflecting whether a relative or someone close died as a consequence of a } \\
\text { bombing raid during the Civil War. }\end{array}$ \\
\hline Direct political violence & $\begin{array}{l}\text { Dummy variable reflecting whether the actual respondent suffered political violence during the } \\
\text { Civil War. }\end{array}$ \\
\hline \multicolumn{2}{|l|}{ Basic control variables } \\
\hline Age & Age of the respondent. \\
\hline Woman & Dummy variable indicating whether the respondent is a woman. \\
\hline Religiosity & $\begin{array}{l}\text { Importance of religion for the individual, measured on a scale from } 0 \text { (minimal importance) to } 10 \\
\text { (maximum importance). }\end{array}$ \\
\hline Size of municipality & Population (in 10,000 inhabitants) of the town in which the respondent resides. \\
\hline $\begin{array}{l}\text { Secondary education, Higher } \\
\text { education }\end{array}$ & $\begin{array}{l}\text { Two dummy variables indicating whether the respondent has completed secondary schooling or } \\
\text { higher education. }\end{array}$ \\
\hline $\begin{array}{l}\text { Family affinity with } \\
\text { Nationalists or Republicans }\end{array}$ & $\begin{array}{l}\text { Two dummy variables reflecting whether the respondent's family had political sympathy with } \\
\text { the Nationalists (Francoist) or loyalists (Republican) during the Civil War. }\end{array}$ \\
\hline Regional dummies & Set of dummy variables corresponding to Spain's 17 Autonomous Communities. \\
\hline \multicolumn{2}{|l|}{ Additional control variables } \\
\hline $\begin{array}{l}\text { Repression during } \\
\text { Francoism }\end{array}$ & $\begin{array}{l}\text { Binary indicator measuring whether the respondent, a relative or someone close suffered political } \\
\text { repression during the Francoist dictatorship. }\end{array}$ \\
\hline $\begin{array}{l}\text { Average political violence: } \\
\text { current province, childhood } \\
\text { province, Civil War } \\
\text { province }\end{array}$ & $\begin{array}{l}\text { Three variables indicating the percentage of individuals reporting political violence during the } \\
\text { Civil War (i.e., the average of the variable 'Political violence'), calculated: i) for the provinces } \\
\text { where the respondents reside, ii) for the provinces where the respondents spent their childhood } \\
\text { and adolescence, iii) for the provinces where the respondents' parental family lived during the } \\
\text { Civil War. }\end{array}$ \\
\hline $\begin{array}{l}\text { Level of knowledge about } \\
\text { the war }\end{array}$ & $\begin{array}{l}\text { The first principal component of six dummy variables indicating whether the respondent } \\
\text { answered differently to 'does not know'/'does not answer' to the following questions related to } \\
\text { the Civil War: 1) whether the family had political sympathy with one or other of the two sides, 2) } \\
\text { the province of residence of the paternal family, 3) the size of the municipality of the paternal } \\
\text { family, 4) whether a relative or someone close suffered violence, 5) which side caused more } \\
\text { deaths, and 6) who was mainly responsible for the outbreak of the war. Since these are binary } \\
\text { variables, we perform the principal component analysis on the polychoric correlation matrix. }\end{array}$ \\
\hline $\begin{array}{l}\text { Father's ideology, Mother's } \\
\text { ideology }\end{array}$ & $\begin{array}{l}\text { Two variables indicating the political identity of the respondent's father and mother, measured } \\
\text { by an indicator that takes values from } 1 \text { (extreme left) to } 10 \text { (extreme right). }\end{array}$ \\
\hline $\begin{array}{l}\text { Father's extremism, } \\
\text { Mother's extremism }\end{array}$ & $\begin{array}{l}\text { Two indicators measuring the political extremism of the respondent's father and mother, with } \\
\text { values ranging from } 0 \text { (positions } 5 \text { and } 6 \text { on the ideological scale) to } 4 \text { (positions } 1 \text { and } 10 \text { on the } \\
\text { scale). }\end{array}$ \\
\hline
\end{tabular}


Description of variables (Continued)

\begin{tabular}{ll}
\hline \multicolumn{1}{c}{ Variable } & \multicolumn{1}{c}{ Description } \\
\hline Mechanisms & $\begin{array}{l}\text { Binary indicator measuring whether the respondent's family used to talk about the Civil War } \\
\text { during the respondent's childhood and adolescence. } \\
\text { Binary indicator measuring whether the respondent was often exposed to political conversations } \\
\text { at home during the respondent's childhood and adolescence. }\end{array}$ \\
Political conversations & $\begin{array}{l}\text { Two dummy variables reflecting whether thinking about the Civil War makes the respondent } \\
\text { feel (in first or second place) rage or fear. }\end{array}$ \\
$\begin{array}{l}\text { Thinking about the Civil } \\
\text { Page/ Fear }\end{array}$ & $\begin{array}{l}\text { Indicator of the respondent's political extremism, taking values from } 0 \text { (positions } 5 \text { and } 6 \text { on the } \\
\text { ideological scale) to 4 (positions } 1 \text { and } 10 \text { on the scale). }\end{array}$
\end{tabular}

Other indicators of political attitudes and behavior

Agreeing with: Politics only Binary indicator that reflects whether the respondent agrees with the statement that politics only creates conflicts creates conflicts and divisions.

Agreeing with: it is Binary indicator that reflects whether the respondent agrees with the statement that it is very important to be politically informed important to be informed about politics.

Reading the political section Variable measuring how often the respondent reads the political sections in newspapers, with in newspapers values ranging from 0 (never) to 4 (daily).

Listening/watching the news Variable measuring how often the respondent listens to or watches the news, with values ranging from 0 (never) to 4 (daily).

Obtaining political Variable measuring how often the respondent uses the Internet to obtain political information, information via the Internet with values ranging from 0 (never) to 4 (daily).

Level of knowledge about Indicator about political knowledge created by combining the answers to three questions asking politics about Spanish political issues. The scale of this indicator ranges from 0 (all wrong answers) to 3 (three correct answers).

Agreeing with: it is better Dummy variable indicating whether the respondent agrees with the statement that it is better not not to get involved in politics to get involved in politics.

Agreeing with: democracy Dummy variable indicating whether the respondent agrees with the statement that for democracy works better with participation

Actual participation: last year to work well, citizens must participate in politics.

Dummy variable measuring whether in the last year the respondent has taken part in any one of the following actions: writing to the press to complain, contacting public officials, participating in a strike or demonstration, or signing a petition.

Actual participation: once

Dummy variable measuring whether the respondent has taken part at least once in any one of the following actions: writing to the press to complain, contacting public officials, participating in a strike or demonstration, or signing a petition.

Voted in the last elections Dummy variable indicating whether the individual voted in the last parliamentary elections held in March 2008.

Notes:

1. The source is "Estudio: 2760. Memorias de la Guerra Civil y el Franquismo." Centro de Investigaciones Sociológicas, Madrid. Available at http://www.cis.es/. 